\title{
Purwarupa Radar sebagai Pendeteksi Benda Diam menggunakan Ultrasonik
}

\author{
LUKY RENALDI, SUGONDO HADIYOSO, DADAN NUR RAMADAN
}

Fakultas Ilmu Terapan Universitas Telkom

Email : lukyrenaldi@gmail.com

Received 30 April 2018 | Revised 8 Juli 2018 | Accepted 28 September 2018

\begin{abstract}
ABSTRAK
Deteksi keberadaan objek secara otomatis pada ruangan diperlukan ketika terdapat keterbatasan dalam melakukan penginderaan. Pemanfaatan sistem radar menjadi saah satu solusi untuk penginderaan objek. Pada paper ini, diimplementasikan prototipe radar menggunakan sensor ultrasonik, mikrokontroller Arduino UNO R3 dan motor servo. Sistem ini dirancang dengan tiga buah sensor ultrasonik dengan motor sebagai penggerak horizontal dan vertikal dalam sistem pemindainya. Sensor yang berjumlah tiga buah, diletakkan pada titik yang berbeda sehingga dapat membaca jarak, sudut dan ketinggian objek dari arah titik tersebut, hasil dari pengukuran objek ditampilkan pada PC melalui aplikasi pemograman GUI. Dari hasil pengujian, radar mampu mendeteksi objek antara $5 \mathrm{~cm}$ dari depan radar dengan jarak maksimum $30 \mathrm{~cm}$ dan diperoleh tingkat kesalahan pengukuran jarak dan ketinggian sebesar 1 - 2 cm sedangkan untuk sudut $1^{\circ}-3^{\circ}$.
\end{abstract}

Kata kunci: Deteksi, Radar, Ultrasonik, Jarak, Sudut

\begin{abstract}
Automatic detection of objects in the room is required when there are limitations in the sensing. Utilization of radar system becomes one solution for sensing object. In this paper, we implemented a prototype radar using ultrasonic sensor, Arduino UNO R3 microcontroller and servo motor. The system is designed with three ultrasonic sensors with motors as horizontal and vertical drive in the scanning system. Three sensors are placed at different points so that they can read the distance, angle and height of the object from that point, the result of measuring the object displayed on the PC through the GUI programming application. From the test results, the radar is able to detect objects between 5 $\mathrm{cm}$ from the front of the radar with a maximum distance of $30 \mathrm{~cm}$ and obtained the error rate measurement of distance and altitude of $1-2 \mathrm{~cm}$ while for the angle of $1^{\circ}-3^{\circ}$.
\end{abstract}

Keywords: Detection, Radar, Ultrasonic, Distance, Angle 
Renaldi, dkk

\section{PENDAHULUAN}

Keterbatasan pandangan dalam mendeteksi keberadaan objek sebagai akibat dari keterbatasan jarak pandang, kondisi cahaya maupun penghalang menjadi permasalahan pada aplikasi kontrol dan monitoring. Penggunaan radar menjadi salah satu solusi untuk mengatasi kondisi tersebut. Radar singkatan dari Radio Detection and Ranging adalah perangkat yang berfungsi untuk menentukan jarak, arah, atau kecepatan dari objek bergerak dan tetap (Rustamaji \& Djaelani, 2012). Rada $r$ dapat digunakan pada aplikasi pemetaan dan eksplorasi objek pada ruang yang tidak diketahui. Penggunaan radar juga dapat membantu navigasi objek bergerak (Hedgire \& Killarikar, 2017). Implementasi radar dapat memanfaatkan prinsip pancaran dan pantulan gelombang elektromagnetik atau gelombang suara pada level energi dan selang waktu tertentu. Dengan melakukan penerapan komputasi matematis, akan diperoleh sebuah gambaran visual representasi dari objek yang sedang diobservasi.

Pada penelitian (Bergeon, Hadda, Krivanek, Motsch, \& Stefek, 2015), diimplementasikan sebuah sistem pemetaan 3 dimensi untuk navigasi pada ruangan menggunakan kamera sebagai detektornya. Namun resource yang digunakan masih cukup besar yaitu penggunaan PC dan kamera kinect Xbox sebagai pengolah data. Penggunaan radar sebagai detektor keberadaan objek yang berada didalam tanah sangat membantu efisiensi dan efektifitas dalam memperkirakan lokasi objek seperti yang dilaporkan pada penelitian (Amir, 2015) (Hemeda, 2012) (Amir, 2013). Pada penelitan tersebut, radar berbasis gelombang elektromagnetik yang dipancarkan oleh antena ke dalam tanah yang kemudian mendeteksi gelombang pantulan dengan level yang berbeda sesuai dengan sifat homogen tanah. Radar ini mampu mengidentifikasi objek dimana terdapat penghalang antara radar dan objek yang dideteksi, namun membutuhkan material dan komputasi yang kompleks. Oleh karena itu, diperlukan sistem radar dengan material serta komputasi sederhana sebagai alternatif yang dapat mendeteksi keberadaan objek pada kondisi tanpa penghalang. Beberapa sensor yang dapat dimanfaatkan untuk mendeteksi keberadaan objek antara lain sensor ultrasonik dan infra merah. Pembuatan radar berbasis ultrasonik sebagai komponen detektor telah dilaporkan pada penelitian (Paulet, Salceanu, \& Neacsu, 2016) dan (Tedeschi, Calcaterra, \& Benedetto, 2017). Pada peneltian tersebut dibuat radar digital berbasis ultrasonik terintegrasi dengan motor untuk memindai objek yang kemudian ditampilkan pada layar LCD dan mobile phone. Namun sistem radar ini tidak dapat digunakan untuk memindai kedalaman atau ketinggian objek karena hanya menggunakan satu buah sensor ultrasonik. Hal yang sama juga dilaporkan pada penelitian implementasi sensor ultrasonik sebagai pemindai objek untuk aplikasi radar (Jain, Thakrani, Mukhija, Anand, \& Sharma, 2017) dan (Latha, Murthy, \& Kumar, 2016). Pada penelitian ini sistem radar hanya mampu mendeteksi benda dari satu sisi. Pada penelitian oleh (Ramadhan, 2012), membuat detektor objek menggunakan sensor infra merah Sharp GP2Y0A21 yang dapat memindai objek dari satu sisi. Simulasi penggunaan ultrasonik sebagai sistem radar dilakukan oleh (R.S.Agarwal, Kumar, V.Thirumala, \& Kumar, 2017), namun sistem yang dibuat belum dilengkapi motor sehingga tidak dapat melakukan pemindaian secara dinamis.

Berdasar uraian yang telah dijelaskan mengenai manfaat pengunaan radar dan studi yang berkaitan dengan implementasi radar, maka sebuah sistem radar sangat berguna untuk memindai objek atau pemetaan suatu area. Pemilihan metode serta penggunaan material detektor disesuaikan dengan kondisi keberadaan objek yaitu berpenghalang atau tanpa penghalang. Keakuratan deteksi dan detail informasi dimensi objek menjadi ukuran performa yang harus dicapai pada implementasi radar dengan tetap memperhatikan efisiensi 
perangkat serta komputasi. Pada penelitian ini, dibuat sebuah prototype radar dengan tiga buah sensor ultrasonik dan motor sebagai penggerak dalam sistem pemindainya. Kendali pergerakan motor dilakukan oleh mikrokontroler Arduino berbasis kontrol Pulse Width Modulation (PWM). Dibandingkan dengan studi yang dilakukan sebelumnya pada penjelasan di atas, implementasi tiga buah sensor pada sistem radar yang diusulkan ini dapat memindai dari tiga arah yang berbeda sehingga dapat membaca jarak, sudut dan ketinggian objek yang disajikan pada aplikasi Graphical User Interface (GUI). Prototipe radar ini diharapkan dapat digunakan untuk identfikasi lokasi keberadaan objek maupun penghalang pada ruangan yang memiliki keterbatasan akses maupun area yang berbahaya.

\section{DESAIN DAN IMPLEMENTASI}

Pada penelitian ini, proses mendeteksi objek digunakan sebuah sensor HC-SR04 (Sensor Ultrasonik), dimana sensor tersebut memiliki dua buah elemen, yaitu elemen pembangkit gelombang ultrasonik (transmitter) dan elemen pendeteksi gelombang ultrasonik (receiver). transmitter memancarkan 8 gelombang dengan frekuensi $40 \mathrm{KHz}$ dalam waktu 10uS (HCSR04 Datasheet, 2018), apabila gelombang yang dipancarkan transmitter mengenai sebuah objek, maka gelombang tersebut akan terpantulkan oleh objek tersebut, sehingga gelombang yang dipantulkan kembali dapat diterima oleh receiver, seperti pada Gambar 1.

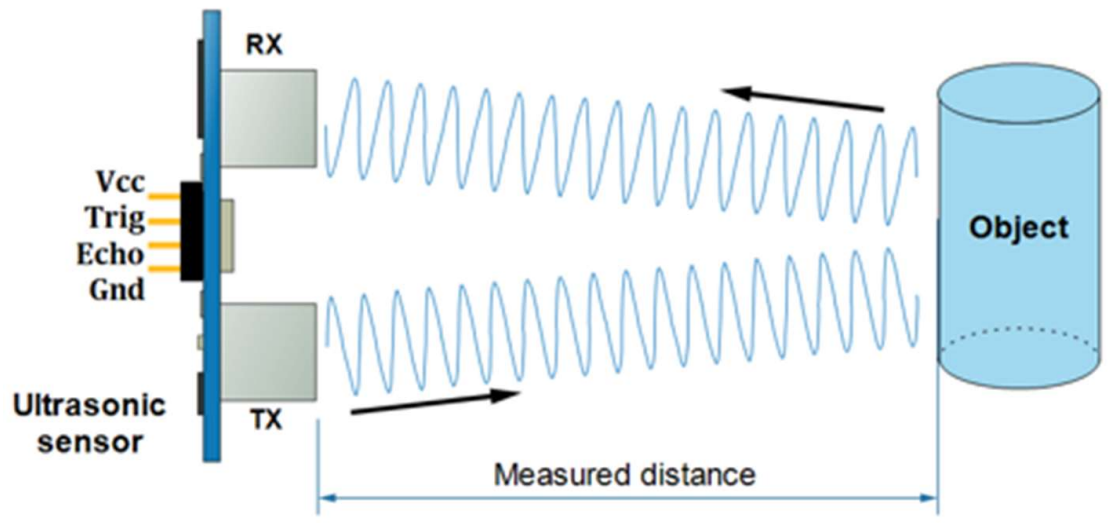

\section{Gambar 1. Cara kerja sensor ultrasonik}

Kemudian sensor akan menghitung selisih waktu jeda antara proses pengiriman dan penerimaan gelombang pantul untuk menentukan berapa jarak antara sensor ke objek, seperti pada Persamaan (1) berikut.

$$
\operatorname{Jarak}(\mathrm{cm})=\frac{\text { Lebar pulsa } \times 0,034}{2}
$$

Proses menghitung jarak serta ketinggian sebuah objek digunakan tiga buah sensor ultrasonik, setiap sensor ultrasonik ditempatkan pada sebuah Nylon PT pan/tilt Camera Mount, yang dilengkapi dengan dua buah motor servo seperti pada Gambar 2, sehingga sensor ultrasonik dapat bergerak ke dua arah yaitu sumbu $x$ dan y secara bersamaan. 


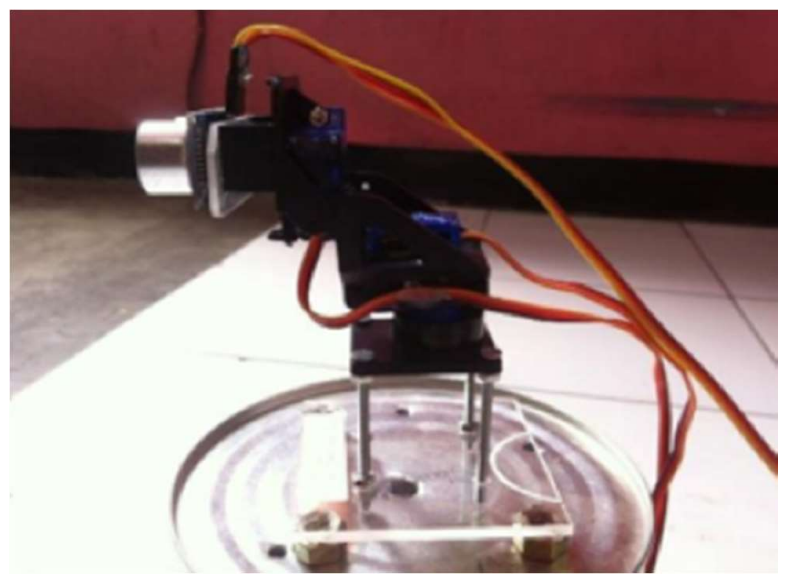

Gambar 2. Realisasi hardware radar

Persamaan trigonometry digunakan untuk mengukur ketinggian dari objek yang terdeteksii oleh sensor ultrasonik (Gambar 3) dengan menggunakan rumus trigonometry sebagai berikut.

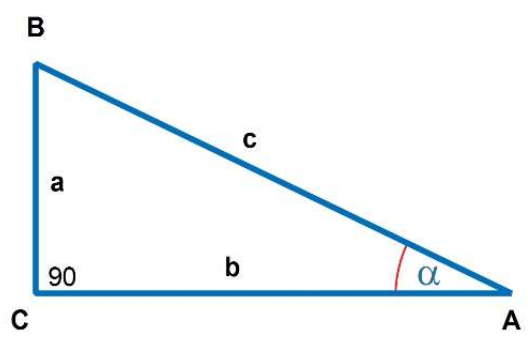

Gambar 3. Trigonometry

Dimana untuk menghitung tinggi (a) dapat menggunakan Persamaan (2) dan Persamaan (3) sebagai berikut:

$$
\begin{gathered}
\sin a=\frac{a}{c} \\
a=\sin a x c
\end{gathered}
$$

Pergerakan motor servo dikontrol menggunakan sinyal PWM melalui mikrokontroler Arduino. Output PWM berupa gelombang berbentuk pulsa dengan lebar pulsa dapat diatur (Effendi, Sara, \& Lubis, 2017). Lebar pulsa PWM ini disesuaikan dengan arah pergerakan motor servo yang diinginkan. Untuk mendapatkan hasil analog dengan output digital pada mikrokontroler, output berupa pulsa digital digunakan untuk membuat gelombang persegi, dimana sinyal memiliki pola on dan off. Pola on-off tersebut mensimulasikan tegangan dari 0 volt (off) dan 5 volt (on), dengan mengatur durasi sinyal on atau sinyal off dari sinyal output mikrokontroler. Ilustrasi control PWM pada motor dapat dilihat pada Gambar 4. 


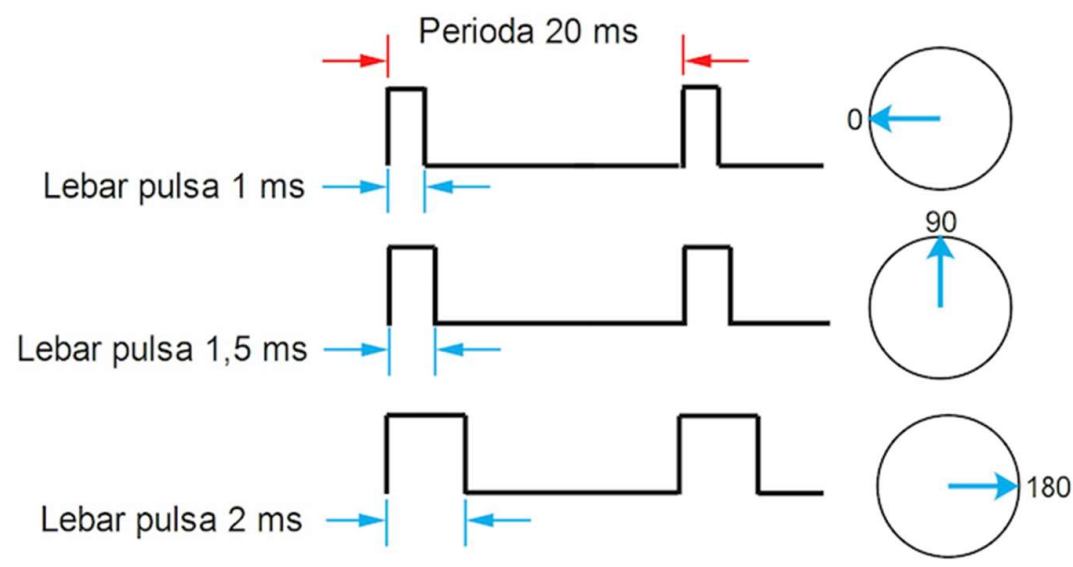

\section{Gambar 4. Kontrol PWM pada pergerakan motor}

PWM diberikan kepada dua buah motor servo yang terpasang pada sebuah Nylon PT pan/ tilt Camera Mount, untuk membuat sensor ultrasonik dapat bergerak dalam sumbu $\mathrm{x}$ dan $\mathrm{y}$, sehingga area pengamatan sensor tersebut tidak ke arah depan saja, tetapi selebar $180^{\circ}$ pada sumbu $x$, dan $45^{\circ}$ pada sumbu $y$. Penambahan $r+=5$ digunakan memutar motor servo sehingga terjadi perubahan sudat sebanyak $5^{0}$ pada sumbu $x$ dan y secara konstan, dengan flowchart pada mikrokontroler seperti pada Gambar 5. Berikut.
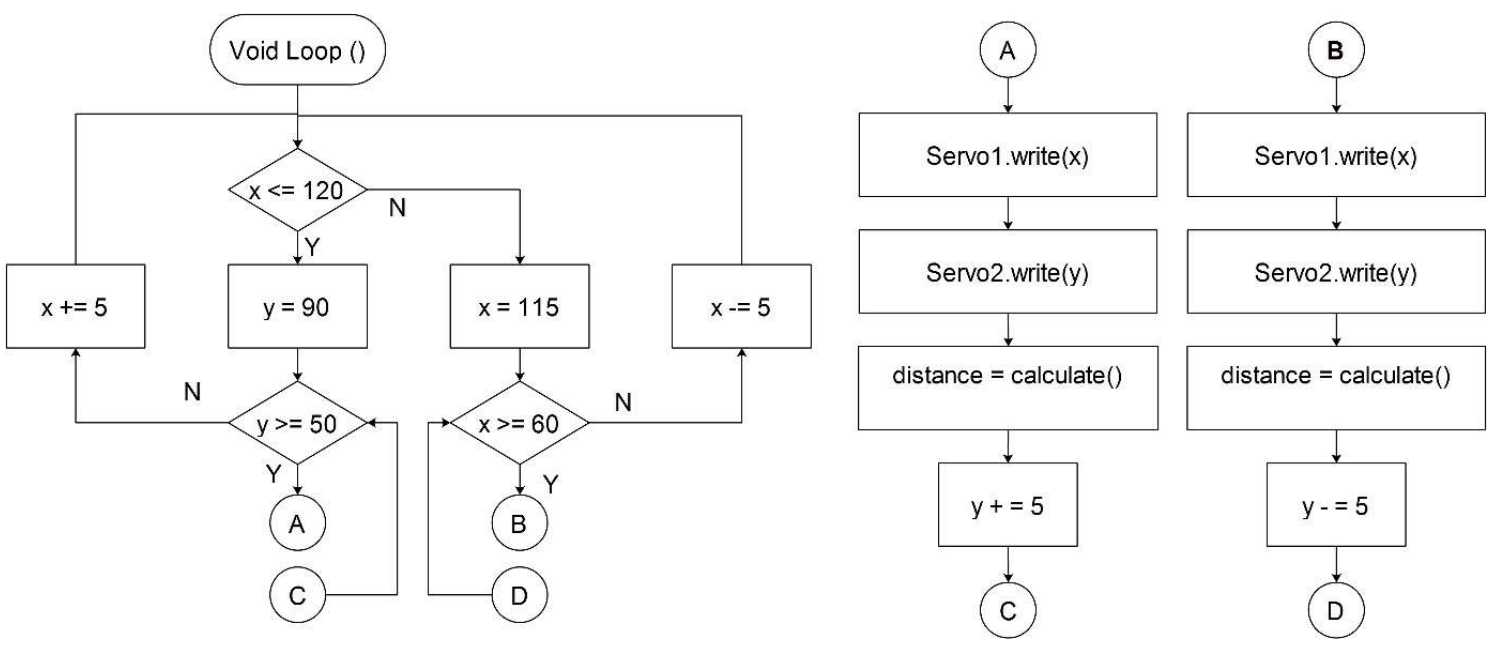

Gambar 5. Flowchart pergerakan motor servo

Dengan sensor ultrasonik diperoleh jarak (c) dan berdasarkan PWM pergerakan motor servo pada sumbu y diperoleh besaran sudut a, sehingga berdasarkan Persamaan (1) dan Persamaan (3), dapat diketahui tinggi dari sebuah objek yang terdeteksi dengan Persamaan (4), yaitu;

$$
a=\sin a \times \frac{\text { lebar pulsa } \times 0,034}{2}
$$

Dikarenakan penempatan sensor ultrasonik pada Nylon PT pan/tilt Camera Mount dapat menambah ketinggian sensor (t) dari tanah, dapat dilihat pada Persamaan (5). Apabila posisi objek yang terdeteksi berada di atas permukaan tanah atau lebih tinggi dari ketinggian sensor, maka ketinggian objek akan dapat dihitung, seperti ilustrasi pada Gambar 6. 


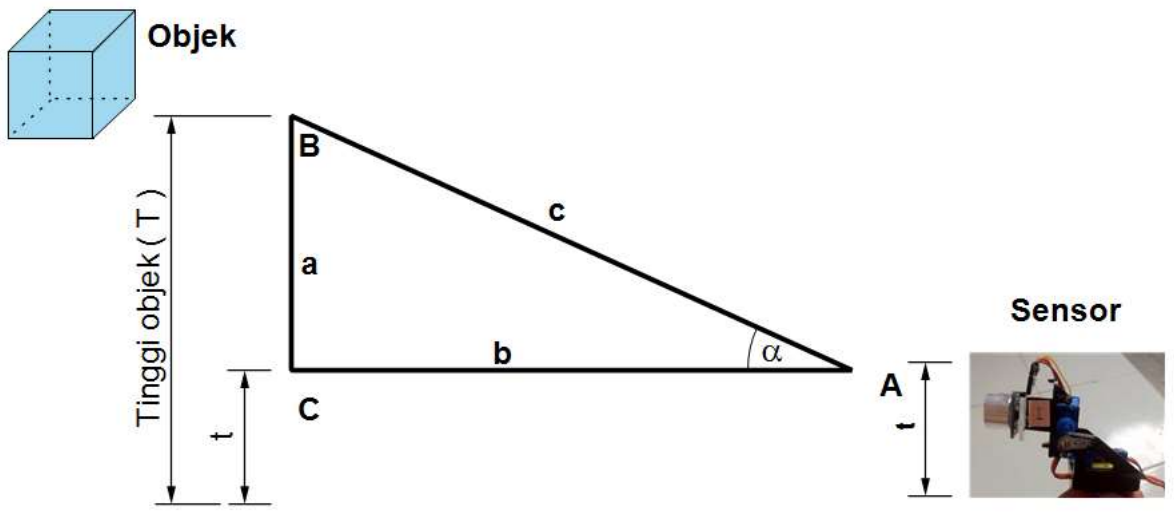

Gambar 6. Kalibrasi ketinggian penempatan sensor

Berdasarkan Gambar 6., maka tinggi objek total $(\mathrm{T})$ adalah jumlah dari tinggi sensor ( $\mathrm{t}$ ) dan tinggi objek (a) seperti pada Persamaan 5, sehingga:

$$
T=a+t
$$

Aplikasi program menggunakan GUI dibuat dengan bahasa pemprograman java, dan dipergunakan untuk merepresentasikan hasil dari proses deteksi objek yang dilakukan oleh setiap sensor ultrasonik. Objek yang terdeteksi akan ditampilakan pada GUI berupa jarak objek tersebut dari sensor dan ketinggian objek dari tanah. Apabila objek tidk terdeteksi oleh salah satu atau semua sensor, maka GUI tidak akan menampikan hasil pemindaian.

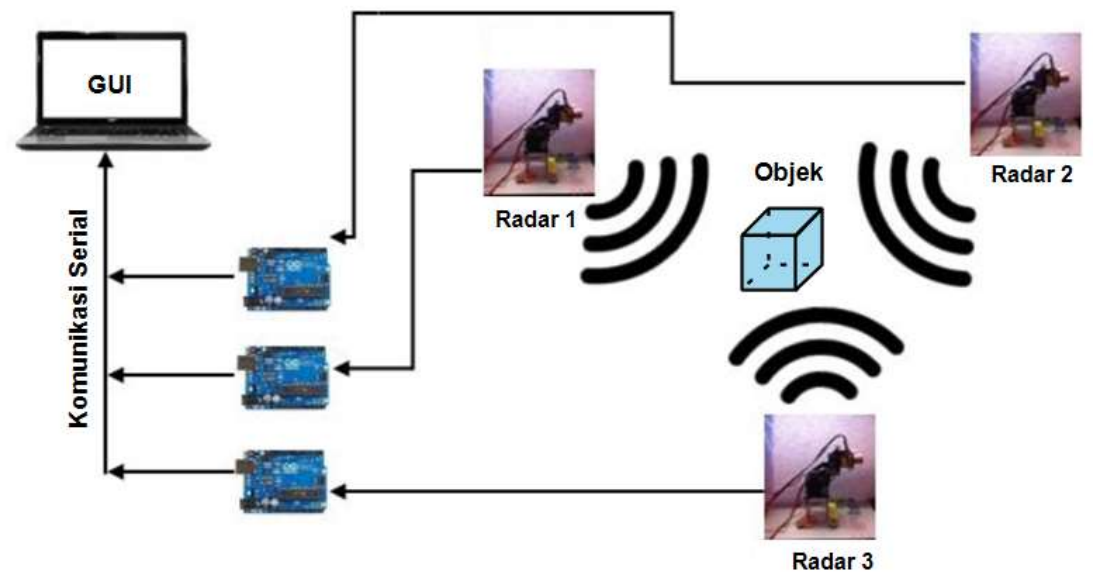

Gambar 7. GUI aplikasi dan penempatan sensor radar

Untuk menunjukan adanya objek yang terdeteksi, digunakan fungsi gambarObjek(), fungsi ini akan mengambil data jarak dari sensor ultrasonik, kemudian mengolah data tersebut menjadi pixel yang dikombinasikan dengan fungsi gambarGaris(), yang berfungsi untuk menampilkan garis sudut pandang ke objek yang terdeteksi. Hasil deteksi objek yang ditampilkan pada aplikasi dapat dilihat pada Gambar 8. 


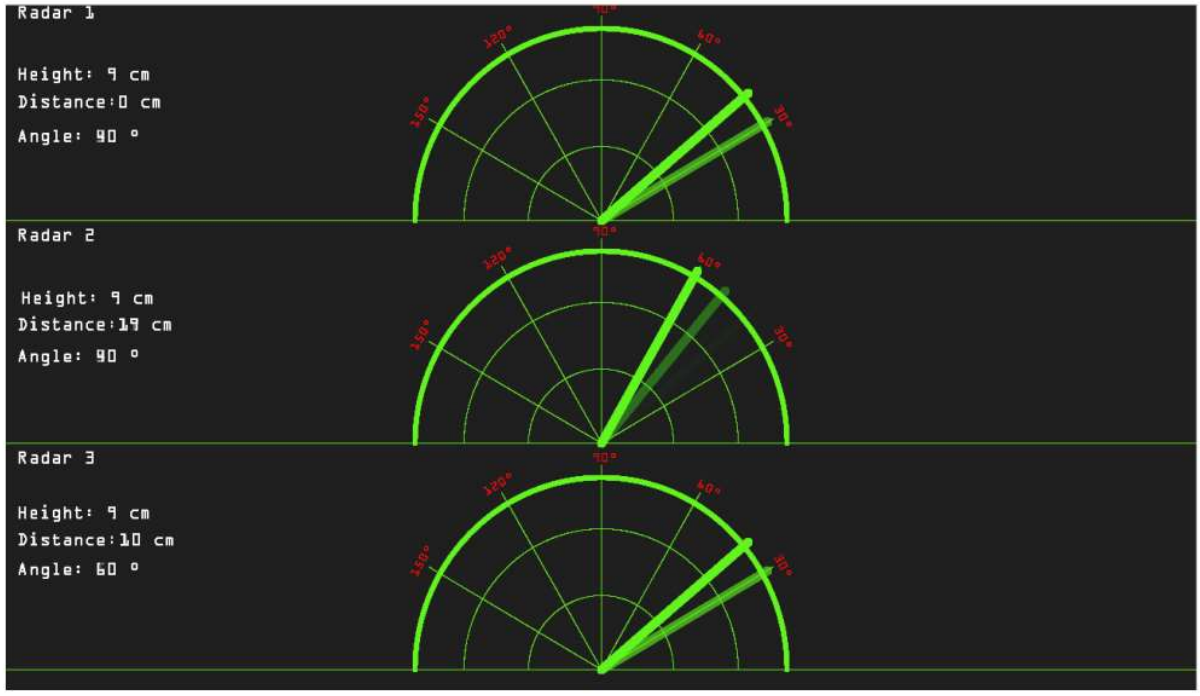

\section{Gambar 8. Tampilan GUI aplikasi radar}

Pada Gambar 8 adalah tampilan GUI yang dibuat, dimana sebuah objek yang posisinya berada di antara ketiga sensor radar dan terdeteksi oleh ketiga sensor radar seperti pada Gambar 9. Berdasarkan informasi GUI pada Gambar 8, dapat diketahui objek berjarak $0 \mathrm{~cm}$ dengan ketinggian $9 \mathrm{~cm}$ dan sudut $90^{\circ}$ dari sensor radar 1 . Objek tersebut juga terdeteksi dari sensor radar 2, dengan berjarak $19 \mathrm{~cm}$, ketinggian $9 \mathrm{~cm}$ dan sudut $90^{\circ}$. Sedangkan dari sensor radar 3 pembacaan objek berjarak $10 \mathrm{~cm}$ dengan ketinggian $9 \mathrm{~cm}$ dan sudut $60^{\circ}$. Garis hijau menunjukan arah sensor radar ketika melakukan pendeteksian sambil bergerak.

\section{HASIL DAN DISKUSI}

\subsection{Pengujian Pembacaan Jarak}

Pengujian radar dilakukan dengan objek berbentuk kubus dengan ukuran $5 \times 5 \mathrm{~cm}$ seperti pada Gambar 9 dengan tahapan awal pengukuran jarak secara bergantian. Berikut hasil pengukuran jarak radar 1 , radar 2 dan radar 3 terhapap objek dapat dilihat pada Tabel 1 dan Gambar 10.

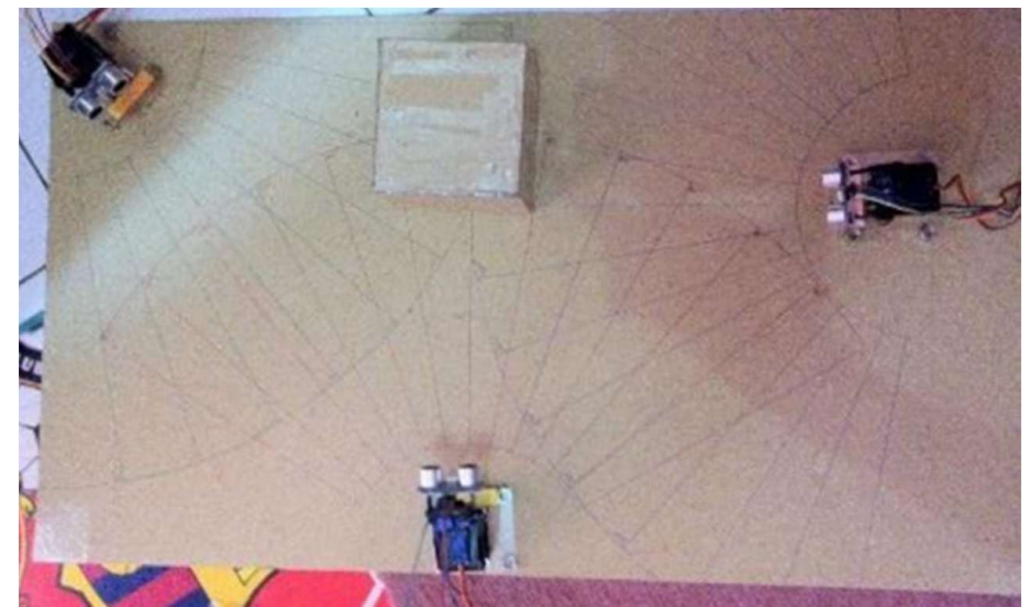

Gambar 9. Simulasi pengujian 3 buah sensor radar terhadap objek kubus 
Tabel 1. Hasil pengukuran jarak radar 1, radar 2 dan radar 3

\begin{tabular}{|c|c|c|c|c|c|c|c|}
\hline Pengujian & $\begin{array}{c}\text { Jarak } \\
\text { objek } \\
(\mathrm{CM})\end{array}$ & $\begin{array}{c}\text { Pembacaan } \\
\text { Radar 1 } \\
(\mathrm{CM})\end{array}$ & $\begin{array}{c}\text { error } \\
\text { radar 1 } \\
(\%)\end{array}$ & $\begin{array}{c}\text { Pembacaan } \\
\text { Radar 2 } \\
(\mathrm{CM})\end{array}$ & $\begin{array}{c}\text { error radar } \\
\text { 2 (\%) }\end{array}$ & $\begin{array}{c}\text { Pembacaan } \\
\text { Radar 3 } \\
(\mathrm{CM})\end{array}$ & $\begin{array}{c}\text { error } \\
\text { radar 3 } \\
(\%)\end{array}$ \\
\hline 1 & 30 & 31,2 & $4,00 \%$ & 30,2 & $0,7 \%$ & 31 & $3,3 \%$ \\
\hline 2 & 40 & 41,3 & $3,25 \%$ & 40,7 & $1,8 \%$ & 41 & $2,5 \%$ \\
\hline 3 & 50 & 52,2 & $4,40 \%$ & 52,5 & $5,0 \%$ & 52,1 & $4,2 \%$ \\
\hline 4 & 60 & 62,1 & $3,50 \%$ & 62,4 & $4,0 \%$ & 62,1 & $3,5 \%$ \\
\hline 5 & 70 & 71,8 & $2,57 \%$ & 72,1 & $3,0 \%$ & 71,3 & $1,9 \%$ \\
\hline 6 & 80 & 82,9 & $3,63 \%$ & 79,2 & $1,0 \%$ & 79,8 & $0,3 \%$ \\
\hline 7 & 90 & 93,1 & $3,44 \%$ & 91,2 & $1,3 \%$ & 90,1 & $0,1 \%$ \\
\hline 8 & 100 & 100,4 & $0,40 \%$ & 100,8 & $0,8 \%$ & 102,8 & $2,8 \%$ \\
\hline 9 & 110 & 110,8 & $0,73 \%$ & 110,7 & $0,6 \%$ & 111,3 & $1,2 \%$ \\
\hline 10 & 120 & 125,2 & $4,33 \%$ & 123,2 & $2,7 \%$ & 121,6 & $1,3 \%$ \\
\hline \multicolumn{2}{r|r}{ Rata-rata } & & $3,0 \%$ & & $2,1 \%$ & & $2,1 \%$ \\
\hline
\end{tabular}

Dari hasil pengujian pada Tabel 1, radar dapat mendeteksi jarak sebuah objek dengan ratarata kesalahan $2,41 \%$.

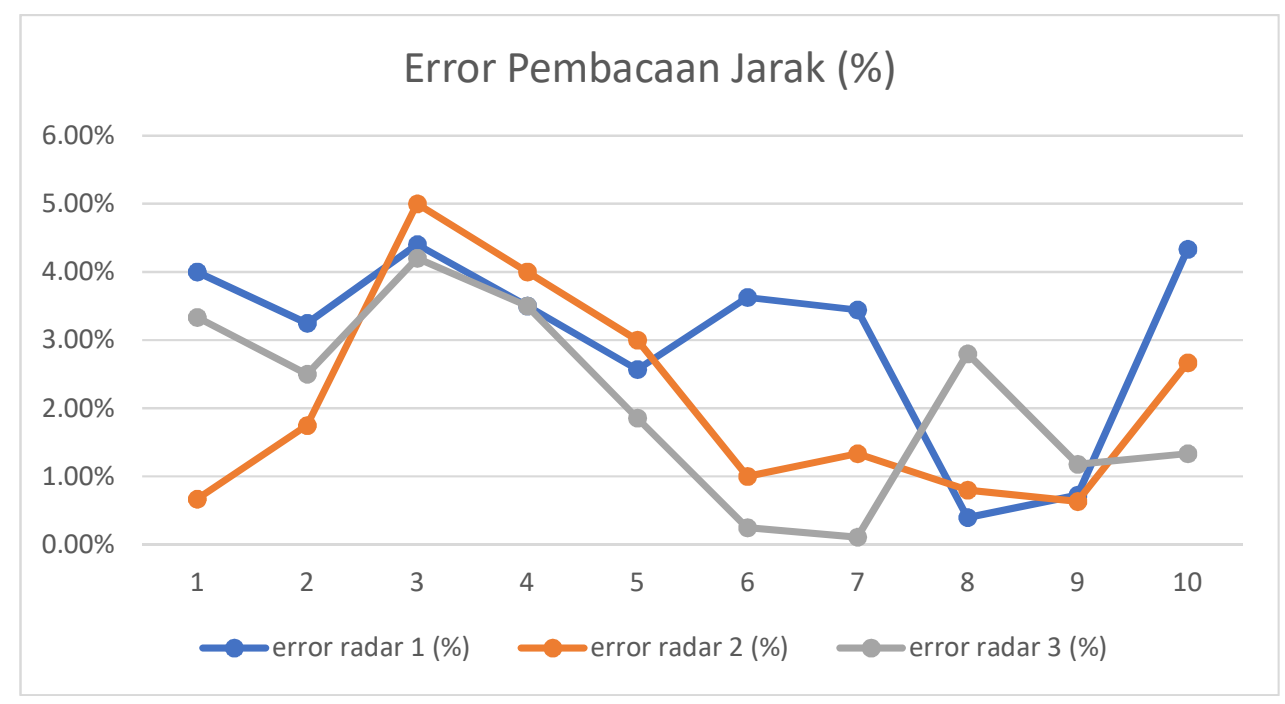

Gambar 10. Nilai kesalahan pembacaan jarak

\subsection{Pengujian pembacaan ketinggian}

Pengujian radar dilakukan dengan objek berbentuk kubus dengan ukuran 5 x $5 \mathrm{~cm}$ dengan tahapan awal pengukuran jarak ketinggian secara bergantian. Berikut adalah hasil pengukuran ketinggian radar 1, radar 2 dan radar 3 terhadap objek dapat dilihat pada Gambar 11 dan Tabel 2. 
Purwarupa Radar sebagai Pendeteksi Benda Diam menggunakan Ultrasonik

Tabel 2. Hasil pengukuran ketinggian radar 1, radar 2 dan radar 3

\begin{tabular}{|c|c|c|c|c|c|c|c|}
\hline Pengujian & $\begin{array}{c}\text { ketinggian } \\
\text { Objek } \\
(\mathrm{CM})\end{array}$ & $\begin{array}{c}\text { Pembacaan } \\
\text { Radar 1 } \\
(\mathrm{CM})\end{array}$ & $\begin{array}{c}\text { error } \\
\text { radar 1 } \\
(\%)\end{array}$ & $\begin{array}{c}\text { Pembacaan } \\
\text { Radar 2 (CM) }\end{array}$ & $\begin{array}{c}\text { error } \\
\text { radar 2 } \\
(\%)\end{array}$ & $\begin{array}{c}\text { Pembacaan } \\
\text { Radar 3 } \\
(\mathrm{CM})\end{array}$ & $\begin{array}{c}\text { error } \\
\text { radar 3 } \\
(\%)\end{array}$ \\
\hline 1 & 5 & 5,1 & $2,00 \%$ & 5,3 & $6,0 \%$ & 4,9 & $2,0 \%$ \\
\hline 2 & 6 & 6,2 & $3,33 \%$ & 6,2 & $3,3 \%$ & 5,9 & $1,7 \%$ \\
\hline 3 & 7 & 7,2 & $2,86 \%$ & 7,3 & $4,3 \%$ & 7,4 & $5,7 \%$ \\
\hline 4 & 8 & 8,3 & $3,75 \%$ & 8,1 & $1,3 \%$ & 7,8 & $2,5 \%$ \\
\hline 5 & 9 & 9,1 & $1,11 \%$ & 9,2 & $2,2 \%$ & 9,1 & $1,1 \%$ \\
\hline 6 & 10 & 10,2 & $2,00 \%$ & 10,2 & $2,0 \%$ & 10,1 & $1,0 \%$ \\
\hline 7 & 11 & 10,9 & $0,91 \%$ & 11,2 & $1,8 \%$ & 11,1 & $0,9 \%$ \\
\hline 8 & 12 & 12,5 & $4,17 \%$ & 12,3 & $2,5 \%$ & 11,9 & $0,8 \%$ \\
\hline 9 & 13 & 13,6 & $4,62 \%$ & 13,2 & $1,5 \%$ & 13,1 & $0,8 \%$ \\
\hline 10 & 14 & 15,1 & $7,86 \%$ & 14,3 & $2,1 \%$ & 14,6 & $4,3 \%$ \\
\hline \multicolumn{2}{r|r}{ Rata-rata } & & $3,3 \%$ & & $2,7 \%$ & & $2,1 \%$ \\
\hline
\end{tabular}

Berdasarkan Tabel 2, radar dapat mendeteksi ketinggian objek dengan rata-rata kesalahan $2,68 \%$.

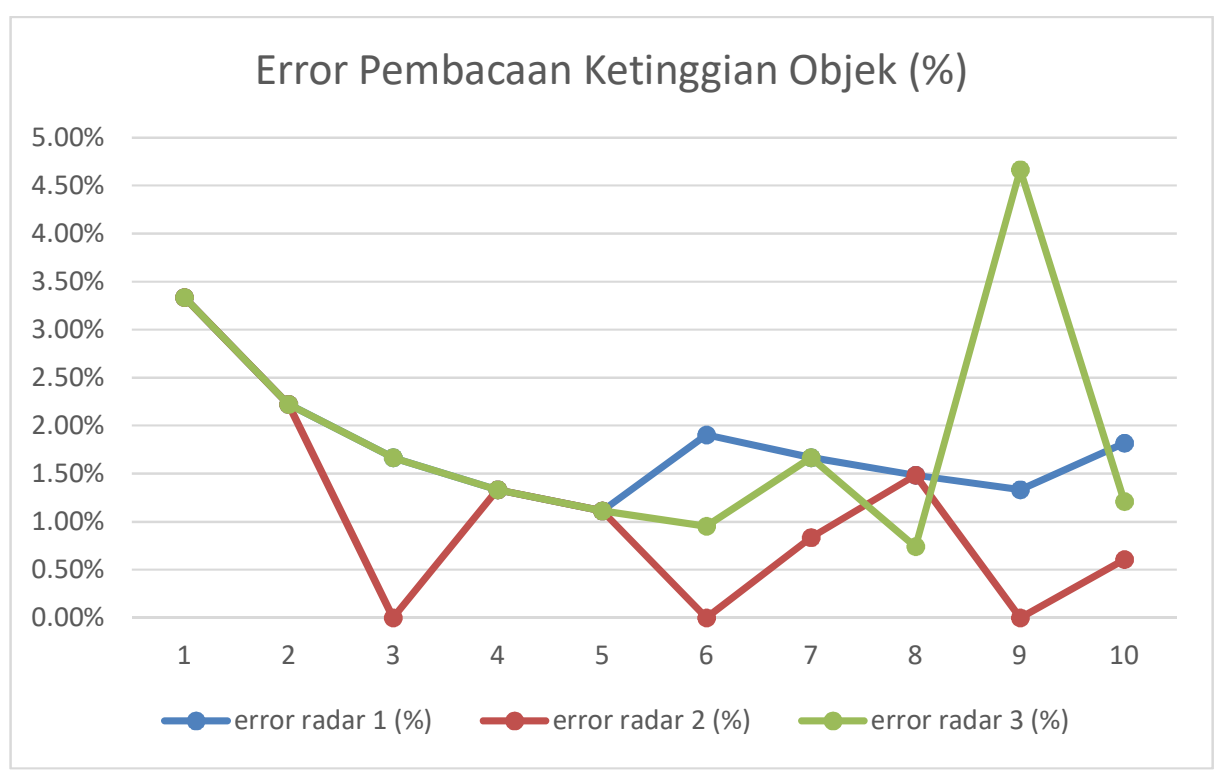

Gambar 11. Nilai kesalahan pembacaan ketinggian

\subsection{Pengujian Pembacaan Sudut}

Pengujian radar dilakukan dengan objek berbentuk kubus dengan ukuran 5 × $5 \mathrm{~cm}$ dengan tahapan awal pengukuran sudut pandang secara bergantian. Berikut hasi pengukuran sudut pandang jarak radar 1, radar 2 dan radar 3 terhapap objek dapat dilihat pada Gambar 12 dan Tabel 3. 


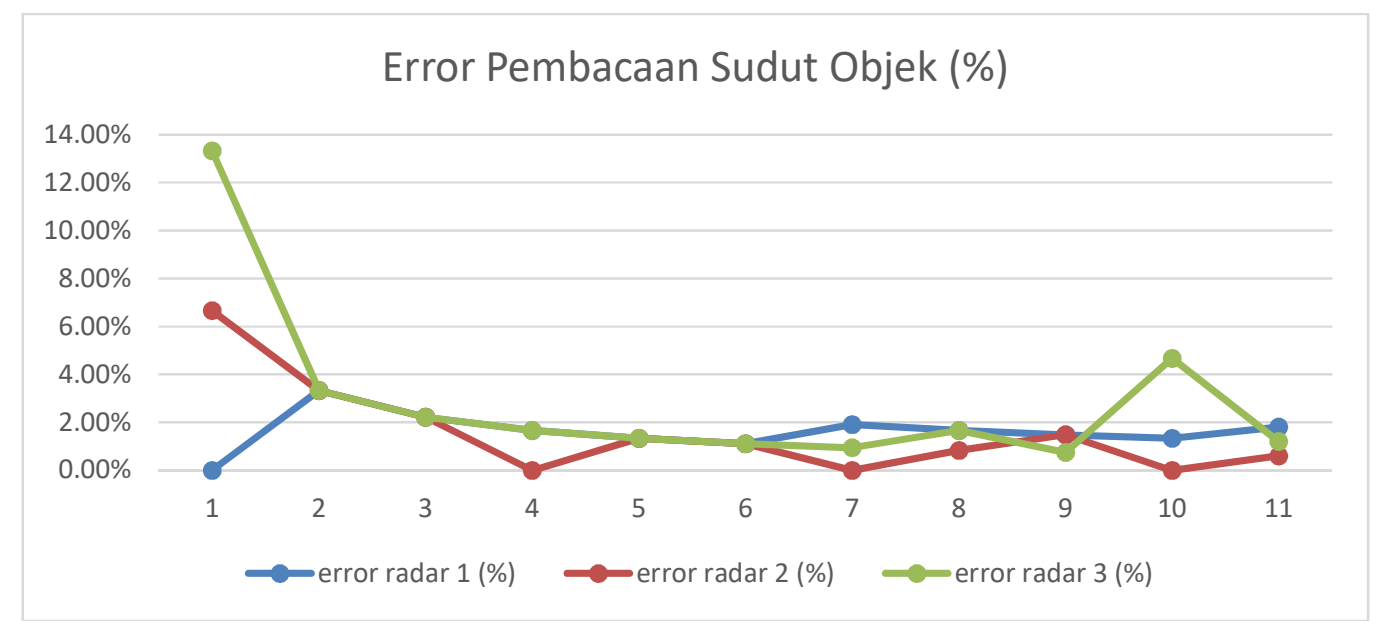

Gambar 12. Nilai kesalahan pembacaan sudut

Kesalahan dalam menentukan jarak, sudut dan ketinggian objek dipengaruhi oleh, keterbatasan resolusi motor servo yang digunakan, tetapi masih dalam toleransi, dikarenakan kesalahan berkisar sebesar 1 - $2 \mathrm{~cm}$ untuk pembacaan jarak dan ketinggian, serta untuk pembacaan sudut sebesar $1^{0}-3^{0}$, untuk pengujian secara lengkap dapat dilihat pada Tabel 3 dengan hasil rata-rata kesalahan adalah 2,05\%.

Tabel 3. Hasil pengukuran sudut radar 1, radar 2 dan radar 3

\begin{tabular}{|c|c|c|c|c|c|c|c|}
\hline Pengujian & $\begin{array}{c}\text { sudut } \\
\text { objek } \\
\left({ }^{0}\right.\end{array}$ & $\begin{array}{c}\text { Pembacaan } \\
\text { Radar 1 }\left({ }^{(}\right)\end{array}$ & $\begin{array}{c}\text { error } \\
\text { radar 1 } \\
(\%)\end{array}$ & $\begin{array}{c}\text { Pembacaan } \\
\text { Radar 2 }\left({ }^{0}\right)\end{array}$ & $\begin{array}{c}\text { error } \\
\text { radar 2 } \\
(\%)\end{array}$ & $\begin{array}{c}\text { Pembacaan } \\
\text { Radar 3 }\left({ }^{(}\right)\end{array}$ & $\begin{array}{c}\text { error } \\
\text { radar 3 } \\
(\%)\end{array}$ \\
\hline 1 & 15 & 15 & $0,00 \%$ & 14 & $6,67 \%$ & 13 & $13,33 \%$ \\
\hline 2 & 30 & 31 & $3,33 \%$ & 29 & $3,3 \%$ & 29 & $3,3 \%$ \\
\hline 3 & 45 & 44 & $2,22 \%$ & 44 & $2,2 \%$ & 44 & $2,2 \%$ \\
\hline 4 & 60 & 61 & $1,67 \%$ & 60 & $0,0 \%$ & 59 & $1,7 \%$ \\
\hline 5 & 75 & 74 & $1,33 \%$ & 76 & $1,3 \%$ & 74 & $1,3 \%$ \\
\hline 6 & 90 & 89 & $1,11 \%$ & 91 & $1,1 \%$ & 91 & $1,1 \%$ \\
\hline 7 & 105 & 107 & $1,90 \%$ & 105 & $0,0 \%$ & 104 & $1,0 \%$ \\
\hline 8 & 120 & 122 & $1,67 \%$ & 121 & $0,8 \%$ & 122 & $1,7 \%$ \\
\hline 9 & 135 & 137 & $1,48 \%$ & 137 & $1,5 \%$ & 134 & $0,7 \%$ \\
\hline 10 & 150 & 148 & $1,33 \%$ & 150 & $0,0 \%$ & 157 & $4,7 \%$ \\
\hline 11 & 165 & 168 & $1,82 \%$ & 166 & $0,6 \%$ & 163 & $1,2 \%$ \\
\hline \multicolumn{2}{|r|}{ Rata-rata } & & $1,6 \%$ & & $1,6 \%$ & & $2,9 \%$ \\
\hline
\end{tabular}

\section{KESIMPULAN}

Dari hasil pengujian dan analisis yang telah dilakukan pada pengukuran jarak, sudut dan ketinggian objek dengan media GUI sebagai outpunya, diperoleh beberapa kesimpulan sebagai berikut:

1. Radar ultrasonik dapat menentukan jarak, sudut dan ketinggian objek dengan tingkat kesalahan sebesar $1-2 \mathrm{~cm}$, sedangkan untuk sudut $10-3^{0}$

2. Rata-rata error pengujian jarak, sudut dan ketinggian objek kurang dari $3 \%$

3. Kecepatan pergerakan servo mempengaruhi pada kepresisian pengukuran. 


\section{DAFTAR RUJUKAN}

Rustamaji, \& Djaelani, E. (2012). Radar Jamming Suatu Konsep Rancang Bangun. Jurnal Electrans, 11(2), 71-80.

Hedgire, D. C., \& Killarikar, S. S. (2017). Ultrasonic Radar Navigation By Using Ultrasonic Sensor, Journal of Emerging Technologies and Innovative Research (JETIR), 4(7), 138140.

Bergeon, Y., Hadda, I., Krivanek, V., Motsch, J., \& Stefek, A. (2015). Low cost 3D mapping for indoor navigation. International Conference on Military Technologies (ICMT) 2015, (pp. 1-5). https://doi.org/10.1109/MILTECHS.2015.7153749

Amir, D. (2015). Rancang Bangun Radar untuk Mendeteksi Saluran Kabel Listrik di Bawah Tanah. Seminar Nasional dan Expo Teknik Elektro, (pp. 108-113)

Hemeda, S. (2012). Ground Penetrating Radar (GPR) Investigations for Architectural Heritage Preservation: The Case of Habib Sakakini Palace, Cairo, Egypt. Open Journal of Geology, 2(3), 189-197. https://doi.org/10.4236/ojg.2012.23019

Amir, D. (2013). Rancang bangun ground penetrating radar untuk mendeteksi saluran pipa bawah tanah. Prosiding SNYuBe, (pp. 169-176)

Paulet, M. V., Salceanu, A., \& Neacsu, O. M. (2016). Ultrasonic radar. Proceedings of the 2016 International Conference and Exposition on Electrical and Power Engineering, EPE 2016, (Epe), (pp. 551-554). https://doi.org/10.1109/ICEPE.2016.7781400

Tedeschi, A., Calcaterra, S., \& Benedetto, F. (2017). Ultrasonic RAdar system (URAS): Arduino and virtual reality for a light-free mapping of indoor environments. IEEE Sensors Journal, 1714), 4595-4604. https://doi.org/10.1109/JSEN.2017.2708840

Jain, A., Thakrani, A., Mukhija, K., Anand, N., \& Sharma, D. (2017). Arduino Based Ultrasonic Radar System using, 5(IV), 215-218

Latha, N. A., Murthy, B. R., \& Kumar, K. B. (2016). Distance Sensing with Ultrasonic Sensor and Arduino, 2(5), 1-5

Ramadhan, R. (2012). Pendeteksi Obyek Di Dalam Ruangan Menggunakan Sensor Infra Merah. Universitas Gunadarma, Jakarta, 1, 1-15

R.S.Agarwal, Kumar, D. V., V.Thirumala, \& Kumar, B. V. (2017). Simulation Of Radar With Ultrasonic Sensors, (April), 88-92

Ultrasonic Ranging Module HC-SR04 Datasheet. (2018). dipetk dari http://www.elecfreaks.com/

Effendi, Sara, I. D., \& Lubis, R. S. (2017). Jurnal Rekayasa Elektrika. Jurnal Rekayasa Elektrika, 13(1), 48-56. https://doi.org/10.17529/jre.v13i2.8093 